\title{
Regulasi Diri dalam Belajar pada Mahasiswa yang Memiliki Peran Banyak
}

\author{
Dwi Nur Rachmah ${ }^{1}$ \\ Program Studi Psikologi Fakultas Kedokteran \\ Universitas Lambung Mangkurat, Banjarmasin
}

\begin{abstract}
This study aimed at identifying and understanding more deeply the selfregulated learning of students with high GPA, who had multiple roles (as housewife and worker also). The approach employed in this study was qualitative-phenomenological approach. The subjects of the study were selected by purposive sampling technique and the data were collected using techniques of observations and in-depth interviews. The results indicated that the four subjects conducted self-regulation in learning through regulating the cognition, motivation, behavior and emotion. Moreover, the subjects performed context regulation in order to achieve certain learning objectives. Selfregulated learning performed by the subjects was influenced by specific precipitating situations and the characteristics of each related individual. It was also strengthened by social support given to them.
\end{abstract}

Keywords: self-regulated learning, student, many roles

Abstrak. Penelitian ini bertujuan untuk mengetahui dan memahami lebih mendalam bagaimana regulasi diri dalam belajar (self regulated learning) mahasiswa yang memiliki banyak peran (sebagai ibu rumah tangga dan bekerja) dengan indeks prestasi tinggi. Pendekatan yang digunakan adalah dengan pendekatan kualitatif-fenomenologi. Subjek penelitian dipilih dengan teknik purposive sampling dan teknik pengumpulan data yang dilakukan adalah menggunakan observasi dan wawancara mendalam. Hasil penelitian menemukan bahwa empat orang subjek menggunakan regulasi diri dalam belajar berupa regulasi kognitif, regulasi motivasi, regulasi perilaku dan regulasi emosi. Selain itu subjek juga melakukan regulasi konteks agar tujuan pembelajaran dapat dicapai. Regulasi diri dalam belajar yang dilakukan oleh para subjek dipengaruhi oleh situasi pencetus dan karakteristik tiap individu bersangkutan. Regulasi diri dalam belajar yang dilakukan juga tidak terlepas dari dukungan sosial yang diberikan kepada mereka.

Kata kunci: regulasi diri dalam belajar, mahasiswa, peran banyak

Wanita pada saat ini menjadi bagian dari perkembangan penduduk Indonesia yang tidak dapat diabaikan perannya. Sensus Badan Pusat Statistik (BPS) tahun 2010 menunjukkan Jumlah wanita yang masuk ke perguruan tinggi dari tahun ke

\footnotetext{
${ }^{1}$ Korespondensi mengenai isi artikel ini dapat melalui: dwi_nurrachmah@yahoo.co.id
}

tahun semakin meningkat yaitu sebanyak 6,13\% di tahun 2009 dan 6,62\% di tahun 2010 (http://.www.bps.go.id). Banyaknya wanita yang memiliki peran ganda, yaitu memiliki dua peran atau lebih, dan pada saat bersamaan menuntut haknya untuk dipenuhi (Irawaty \& Kusumaputri, 2008), menjadi permasalahan sendiri ketika menjalankan peran tidak hanya sebagai 
mahasiswa, tetapi juga menjadi ibu rumah tangga dan wanita karir. Beberapa hasil penelitian (Setyawati, 2010; Utami, 2011) menyebutkan bahwa peran yang dijalani yang lebih dari satu membuat munculnya konflik dalam menjalankan peran tersebut. Hasil penelitian Puwanto (2009) menemukan bahwa mahasiswa yang bekerja dan telah berkeluarga mengalami kesulitan dalam mengatur diri ketika belajar secara mandiri di luar perkuliahan tatap muka yang disebabkan oleh faktor internal seperti malas, kurang gigih, terlalu mengandalkan orang lain dan faktor eksternal yaitu tugas yang banyak di berbagai perannya.

Mahasiswa yang memiliki banyak peran lainnya sangat membutuhkan regulasi diri dalam belajar yang baik agar mendapatkan prestasi akademik yang baik pula seperti yang disebutkan oleh Schaie dan Carstense (2006) bahwa mahasiswa yang juga memiliki peran sosial lain memerlukan regulasi diri dalam pembelajaran yang dijalani, dan pengaruh dari peran yang dimilikinya akan membuat tingkat regulasi diri yang dilakukan lebih besar dibandingkan dengan individu lain yang tidak memiliki peran sosial lainnya. Mahasiswa yang melakukan regulasi diri dalam belajar menurut Pintrich (2003) yaitu mahasiswa yang menetapkan tujuan dan merencanakan kegiatannya, melakukan monitor dan kontrol terhadap aspek kognitif, motivasi serta tingkahlakunya dalam mencapai tujuan tersebut. Mahasiswa yang melakukan regulasi diri dalam belajar ini adalah mahasiswa yang dapat berhasil dalam pendidikannya.

Beberapa hasil penelitian menunjukkan bahwa terdapat hubungan antara regulasi diri dalam belajar dengan peran yang dimiliki oleh mahasiswa. Rescoe, Morgan, dan Peebles (1996) menemukan adanya perbedaan indeks prestasi antara mahasiswa yang bekerja dengan yang tidak bekerja. Mahasiswa yang bekerja memiliki indeks prestasi akademik yang lebih tinggi dibandingkan mahasiswa yang tidak bekerja dikarenakan mahasiswa yang bekerja lebih disiplin, lebih tepat waktu dalam perkuliahan dan memiliki inisiatif untuk berusaha mencari informasi diluar sumber-sumber sosial ketika mengerjakan tugas. Sikap-sikap yang ditunjukkan oleh mahasiswa yang bekerja dalam penelitian Rescoe, Morgan dan Peebles (1996) ini menunjukkan ciri mahasiswa yang melakukan regulasi diri dalam belajar.

Regulasi diri dalam belajar yang baik akan membantu seseorang dalam memenuhi berbagai tuntutan yang dihadapinya. Santrock (2007) menyebutkan adanya regulasi diri dalam belajar akan membuat individu mengatur tujuan, mengevaluasinya dan membuat adaptasi yang diperlukan sehingga menunjang dalam prestasi. Hasil penelitian lainnya juga menunjukkan bahwa regulasi diri dalam belajar mempunyai peranan yang besar dalam pencapaian prestasi akademik seseorang (Zimmerman, 1990; Moltalvo \& Torres, 2004; dan Cheng, 2011).

Cheng (2011) menguraikan bahwa seseorang yang dapat melakukan pembelajaran mandiri memiliki gagasan yang jelas tentang bagaimana dan mengapa strategi regulasi diri dalam belajar harus digunakan. Mereka adalah pembelajar aktif dalam hal metakognisi, motivasi dan kontrol terhadap tindakan. Lebih lanjut dijelaskan oleh Cheng (2011) dalam proses pembelajaran mandiri, seseorang perlu mengatur tujuan pembelajaran mereka, membuat rencana pembelajaran, memilih strategi belajar mereka, memantau proses belajar mereka, mengevaluasi hasil belajar mereka dan menekan gangguan. 
Komponen regulasi diri dalam belajar pada pembelajar sendiri menurut Pintrich (2004) terdiri dari: (1) Kontrol kognitif dan regulasi kognitif merupakan aktivitas kognitif dan metakognitif. (2) Regulasi motivasi mencakup upaya untuk mengatur berbagai keyakinan motivasi. (3) Regulasi perilaku merupakan aspek regulasi diri yang melibatkan upaya individu untuk mengontrol perilaku sendiri, dan (4) Regulasi terhadap konteks merupakan upaya untuk mengontrol konteks dalam menghadapi pembelajaran di kelas.

Mahasiswa yang memiliki peran tidak hanya sebagai mahasiswa tetapi juga sekaligus sebagai ibu rumah tangga dan juga bekerja, dalam kenyataannya dapat memiliki prestasi akademik yang memuaskan ditandai dengan indeks prestasi akademik mereka yang tergolong tinggi. Thomas, Raynor, dan Al-Marzooqi (2012) menyimpulkan dari hasil penelitian mereka bahwa mahasiswa wanita memiliki indeks prestasi akademik yang lebih tinggi dari mahasiswa laki-laki dan mahasiwa wanita yang telah menikah juga memiliki indeks prestasi akademik yang lebih tinggi dibandingkan dengan mahasiswa wanita yang belum menikah. Hasil studi pendahuluan yang dilakukan dalam penelitian ini menemukan bahwa terdapat beberapa orang mahasiswa yang berstatus sudah menikah dan juga tetap menjalankan tugasnya di tempat kerja meskipun sedang menempuh pendidikan pascasarjana. Mahasiswa-mahasiswa ini mampu mencapai indek prestasi akademik yang tergolong tinggi tidak terlepas dari regulasi diri yang mereka lakukan. Hasil studi pendahuluan ini sejalan dengan hasil penelitian dari Spitzer (2000) dan Latifah (2010) yang menemukan bahwa regulasi diri dalam belajar yang dilakukan oleh seseorang berkaitan erat dengan performansi akademiknya.
Hasil-hasil penelitian sebelumnya mengenai regulasi diri dalam belajar belum ada yang menggambarkan fenomena regulasi diri dalam belajar yang dilakukan oleh mahasiswa dengan peran sosial lainnya dan memiliki prestasi akademik tinggi. Gambaran mengenai seperti apa regulasi diri dalam belajar yang dilakukan berdasarkan perspektif mereka sehingga sampai memiliki indeks prestasi akademik yang tinggi dan hal-hal apa saja yang membentuk regulasi diri dalam belajar tersebut berdasarkan karakteristik yang dimiliki belum diketahui secara pasti dan menyeluruh. Hal-hal inilah kemudian menjadi pertanyaan penelitian yang diajukan dalam penelitian ini yaitu: (1) Bagaimanakah regulasi diri dalam belajar yang dilakukan oleh mahasiswa dengan peran sosial yang banyak?, dan (2) Hal-hal apa saja yang membentuk regulasi diri dalam belajar tersebut? Untuk mendapatkan jawaban yang lebih luas cakupannya berdasarkan perspektif individu yang mengalaminya langsung dan mendapatkan makna dari regulasi diri dalam belajar yang dilakukan maka digunakan pendekatan penelitian kualitatif perspektif fenomenologi.

\section{Metode}

\section{Desain dan variabel penelitian}

Penelitian ini menggunakan pendekatan kualitatif perspektif fenomenologi dengan variabel regulasi diri dalam belajar sebagai variabel penelitian yang ingin diteliti secara lebih mendalam. Penelitian dengan metode kualitatif ini sejalan dengan pernyataan Moleong (2011) bahwa penelitian kualitatif merupakan penelitian yang bermaksud untuk memahami fenomena yang dialami oleh subjek penelitian secara menyeluruh dengan cara deskripsi dalam bentuk kata-kata dan bahasa pada 
konteks dan metode alamiah. Perspektif fenomenologi yang digunakan sesuai dengan pernyataan Kuswarno (2009) yang menyebutkan pendekatan kualitatif perspektif fenomenologi adalah merupakan penelitian yang berusaha untuk memahami bagaimana seseorang mengalami dan memberi makna pada sebuah pengalaman.

\section{Subjek penelitian}

Subjek dalam penelitian kualitatif ini disebut dengan subjek. Jumlah subjek yang terlibat dalam penelitian ini sebanyak empat orang, didapatkan dengan menggunakan purposif sampling yang memiliki kriteria; usia berkisar antara 25 sampai dengan 35 tahun, prestasi akademik tergolong tinggi yang ditandai dengan IPK terakhir lebih dari 3.5, dan berstatus sebagai mahasiswa pascasarjana, bekerja dan telah menikah.

\section{Instrumen Penelitian}

Pengumpulan data dilakukan dengan metode wawancara mendalam (in depth interview). Prosedur wawancara dilakukan dengan mengacu pada panduan wawancara yang dibuat oleh peneliti berdasarkan area regulasi diri dalam belajar dari Pintrich (2004). Panduan wawancara yang dibuat adalah dalam bentuk pertanyaan terbuka dimana subjek penelitian dapat menjawab bebas semua pertanyaan yang diajukan oleh peneliti. Wawancara yang dilakukan bersifat semi terstruktur yang berarti bahwa peneliti tidak hanya menanyakan hal-hal yang ada di panduan wawancara saja tetapi pertanyaan lain dapat diajukan oleh peneliti mengikuti respons yang diberikan oleh subjek untuk dapat menggali data lebih dalam. Penelitian ini juga menggunakan observasi untuk melihat secara langsung bagaimana subjek melakukan regulasi diri dalam belajar, sehingga dapat menambah infor- masi selain dari sumber utama yaitu wawancara.

Metode analisis dan interpretasi data kualitatif perspektif fenomenologi yang digunakan dalam penelitian ini adalah menggunakan metode analisis data Stevick-Colaizzi-Keen dari Moustakas (1994), yaitu dengan (1) mendeskripsikan secara lengkap peristiwa atau fenomena yang dialami langsung oleh subjek, (2) dari pernyataan-pernyataan responsden kemudian peneliti; (a) menelaah setiap pernyataan yang berhubungan dengan masalah penelitian, (b) merekam atau mencatat pernyataan yang relevan, dan (c) pernyataan-pernyataan yang telah dibuat kemudian dibuat daftarnya (unit makna fenomena) dan diusahakan agar tidak ada pernyataan yang tumpang tindih atau berulang, (d) Mengelompokkan setiap unit makna ke dalam tema-tema tertentu, (e) membuat sintesis dari unit-unit makna dan tema (deskripsi tekstural), termasuk pernyataan verbal yang menjadi inti unit makna, (f) mempertahankan refleksi penjelasan struktural diri sendiri melalui variasi imajinasi, dimana peneliti membuat konstruk deskripsi struktural, (g) menggabungkan deskripsi tekstural dan struktural untuk menentukan makna dan esensi dari fenomena. (3) Melakukan tahapan pada bagian dua untuk setiap subjek, dan (4) Membuat penjelasan menyeluruh dari setiap makna dan esensi fenomena yang didapat.

\section{H a s i 1}

Penggunaan metode kualitatif dalam penelitian ini sejalan dengan pernyataan dari Pintrich (2000) bahwa diperlukannya suatu deskripsi melalui penelitian etnography dan observasi untuk melihat bagaimana suatu konteks dapat membentuk, memfasilitasi dan membatasi regulasi 
diri dalam belajar. Hasil penelitian yang didapatkan dalam penelitian ini terangkum dalam tema-tema umum yang ditemukan.

\section{Latar Belakang Munculnya Regulasi Diri dalam Belajar}

Para subjek penelitian menyadari bahwa mereka memiliki peran yang banyak sehingga muncul kesadaran untuk mengatur semua aktivitas yang mereka lakukan termasuk aktivitas dalam memenuhi tuntutan belajar mereka di program pascasarjana. Kemampuan mereka dalam melakukan regulasi diri dalam belajar dan juga motivasi berprestasi yang dimiliki membuat mereka mampu mencapai indeks prestasi akademik yang tinggi. Meskipun demikian, mereka juga menyadari bahwa tuntutan-tuntutan yang datang khususnya tuntutan dalam bidang akademik tidak selalu dapat dijalankan mereka dengan lancar dan tanpa hambatan. Beberapa tuntutan ada yang baru dapat dilaksanakan setelah melewati hambatanhambatan yang mereka alami baik karena tugas dituntutan lain ataupun dikarenakan munculnya permasalahan di kehidupannya.

Suku bangsa yaitu suku jawa dengan nilai-nilai yang dianut oleh para subjek dan keyakinan pada Tuhan Maha Esa tercermin dalam nilai-nilai agama yang dipegang oleh para subjek menjadi landasan yang melekat pada keempat subjek. Nilai-nilai ini memunculkan bentukbentuk regulasi diri yang mereka lakukan dalam menghadapi tuntutan belajar di Program Pascasarjana seperti memunculkan sikap sabar, berserah diri, percaya pada kuasa Tuhan, berusaha dengan maksimal apa yang mereka bisa lakukan serta mengontrol emosi mereka. Sikapsikap ini kemudian menghadirkan regulasi diri dalam belajar khususnya regulasi perilaku, regulasi emosi, dan regulasi kognitif.

Subjek penelitian tinggal bersama dengan anggota keluarga lainnya dalam satu atap selain keluarga inti seperti orang tua (subjek $X, S$, dan $N E$ ), saudara (subjek $S$ dan $X$ ), saudara ipar (subjek $E N$ ), keponakan (subjek $E N$ ) ataupun pembantu rumah tangga (subjek $X$ ). Kondisi ini memberi pengaruh terhadap regulasi diri yang dilakukan. Regulasi diri dalam belajar yang dilakukan sangat dipengaruhi oleh dukungan yang diberikan oleh orangorang disekitar subjek penelitian, terutama dukungan dari keluarga. Dukungan dari keluarga dan orang terdekat ini membuat para subjek berupaya untuk menyesuaikan diri dengan banyaknya aktivitas yang dilakukan serta tuntutan peran yang dihadapi.

Subjek penelitian sebagaimana hasil wawancara dengan subjek NE menyebutkan cara yang paling sering ia lakukan yaitu dengan memahami dirinya sendiri bahwa ia merupakan individu yang membutuhkan faktor penguat agar dapat belajar dengan baik. Faktor penguat pada subjek NE ini adalah dukungan dari orang disekitarnya.

"gak ada sih tips yang terlalu gimana itu nggak ya kita kenali diri kita sendiri gitu kita tipenya seperti apa karna aku orang eksternal jadi aku cari dukungan dari luar juga untuk memperkuat niat belajarku tapi emang niat itu yang pertama ya emm..kalau kita udah niat kita senang ya udah jadi jalaninya enak gitu lho mbak" (subjek NE)

Subjek EN juga menyatakan bahwa tugastugas kuliah yang banyak dapat diselesaikan jika tugasnya di peran yang lain telah diambil alih ataupun dibantu oleh orang lain, sehingga memudahkannya untuk fokus ke tugas sebagai mahasiswa. 
"saya kira bantuan dari orang-orang sekitar memang sangat berarti. Tugastugas saya sudah bisa dikerjain oleh orang lain nah saya baru bisa fokus ke tugastugas kuliah" (Subjek EN)

Dukungan sosial yang paling utama didapatkan oleh subjek terutama adalah dukungan dari suami yang turut membantu subjek dalam menyelesaikan tugas kuliah mereka, seperti yang diutarakan oleh subjek $S$ berikut ini.

"suami saya cukup membantu mbak karna diakan orangnya cukup melek IT ya dalam artian dia itu memang telaten kalau pas waktunya senggang browsing buku-buku ebook yang itu memang terkait dengan minat saya" (Subjek S)

Selain dari suami, dukungan dari orang disekitar seperti orangtua sangat memiliki peran yang besar bagi subjek. Dukungan dari orangtua ini menjadi penting bagi subjek terutama bagi subjek $X$ yang tinggal berjauhan dengan suami khususnya dalam membantu menjaga dan mengasuh anaknya.

'dukungan dari orang lain contohnya kayak kemaren tesis itu waktu mau kompre itu kan benar-benar sampai jam delapan sampai perpus tutup gitu mamahku juga udah deh gak papa ntar owa.owa kan nama anakku ta urusin aja owa" (Subjek X)

Gambaran hasil penelitian dari masing-masing subjek penelitian menunjukkan terdapat beberapa kesamaan maupun perbedaan dalam melakukan regulasi diri dalam belajar yang tidak terlepas dari karakteristik pribadi yang dimiliki. Karakteristik baik berupa karakter pribadi ataupun karakteristik dari luar seperti dukungan sosial merupakan karakteristik yang menjadi pemicu munculnya situasi-situasi yang dihadapi para subjek termasuk situasi berupa hambatan atau- pun dukungan yang akhirnya membentuk regulasi diri dalam belajar mereka.

Peranan karakteristik pada regulasi diri dalam belajar subjek

Subjek EN merupakan individu yang memiliki jiwa sosial. Ia selalu berusaha menjalankan berbagai aktivitas yang menurutnya dapat memberikan manfaat bagi orang lain sehingga ia merasa senang menjalankan berbagai peran meskipun aktivitas yang dijalaninya dirasakan berat. Disamping itu, ia mendapatkan dukungan yang besar dari orang lain dalam memenuhi tuntutan diberbagai peran terutama dari suami. Dukungan yang didapatkan dari suami dan anggota keluarganya yang lain membuat ia mampu melakukan regulasi motivasi dan regulasi perilaku dengan baik.

Subjek NE merupakan individu yang mudah terbawa emosi atau perasaan sehingga regulasi diri dalam belajar yang dilakukan didahului dengan mengatur atau melakukan regulasi emosi (afeksi) seperti menjaga perasaannya agar tetap nyaman dan senang sehingga proses pembelajaran dapat berjalan dengan lancar. Regulasi yang cenderung dilakukannya adalah regulasi emosi dan regulasi perilaku.

Subjek $S$, sejak remaja sudah memiliki aktivitas yang banyak pula dalam berbagai peran sehingga ia mampu melakukan strategi regulasi diri dalam belajar yang tepat dalam menghadapi tuntutan belajarnya pada saat mengikuti program pascasarjana. Kecenderungan regulasi diri dalam belajar subjek $S$ lebih kepada regulasi perilaku. Akan tetapi, ketika tuntutan diberbagai peran sangat tinggi dan belum pernah dialami sebelumnya ia mengalami kemunduran dalam melakukan regulasi diri dalam belajar yang ditandai dengan berhenti mengerjakan tesis dan muncul 
berbagai perasaan ketidakmampuan dalam mengerjakan tesisnya. Ketidakmampuan dalam mengatasi berbagai tuntutan ini tidak terlepas pula dari sifatnya yang perfeksionis membuat ia seringkali menunda mengerjakan sesuatu dan berdampak kesulitan baginya untuk mengerjakan dua tugas sekaligus ketika tuntutan yang tinggi datang bersamaan.

Subjek $X$ hidup terpisah dengan suami karena suaminya bekerja di luar kota. $X$ tinggal bersama dengan orang tua, saudara dan pembantu rumah tangga yang membantunya menjalankan aktivitas sehari-hari. Meskipun ia tinggal bersama keluarga dan memiliki pembantu, tetapi ia memiliki peran yang lebih banyak dalam mengurus keperluan rumah tangga. Kondisi ini membuat dirinya kadang-kadang merasa berat menjalankan berbagai peran dan lebih mengutamakan menjaga emosinya tetap stabil sehingga cenderung menggunakan regulasi emosi dan regulasi perilaku.

\section{Bentuk-bentuk Regulasi Diri dalam Belajar}

Bentuk regulasi diri dalam belajar yang ditemukan pada empat orang subjek adalah regulasi dalam hal kognitif, regulasi emosi, regulasi motivasi, regulasi perilaku dan regulasi konteks. Kelima bentuk regulasi diri dalam belajar yang dilakukan oleh para subjek penelitian terjadi karena adanya faktor pencetus munculnya bentuk regulasi tersebut. Faktor-faktor pencetus itu adalah aktivitas yang padat di berbagai peran, kegiatan mengurus anak dan rumah tangga dirumah, cara penilaian dosen yang berbeda, keinginan untuk berhasil di pembelajaran, keterbatasan dana untuk pendidikan, dan hambatan dalam memenuhi tuntutan belajar (lihat Tabel 1).

Kesempatan, Harapan, Tujuan Pribadi dan Rintangan sebagai Makna Regulasi Diri

Seorang wanita ketika dihadapkan dengan tugas-tugas di berbagai perannya tentu tidak mudah untuk dapat fokus ketika memutuskan untuk melanjutkan pendidikan ke jenjang pascasarjana. Akan tetapi, bagi subjek dalam penelitian ini kesempatan yang mereka miliki untuk dapat menambah pengetahuan mereka merupakan kesempatan yang tidak boleh disia-siakan. Kesadaran bahwa kesempatan ini tidak mudah didapatkan dan kesempatan untuk mengembangkan diri melalui pengetahuan menjadi pendorong atau motivasi eksternal yang membuat para subjek senantiasa berusaha dengan sungguh-sungguh dalam menjalani prosesnya.

Harapan untuk mencapai cita-cita masa depan dan impian dengan melanjutkan pendidikan ini akan membawa pengaruh yang baik bagi karir mereka ke depan membuat para subjek menjalani proses pendidikan dengan perasaan senang. Selain itu, adanya dukungan yang besar dari orang-orang terdekat seperti suami dan anggota keluarga lainnya membuat para subjek semakin bersemangat menjalankan kegiatan akademiknya ditengah kesibukan membagi waktu dengan tugas di peran yang lain. 
Tabel 1

Regulasi diri dalam belajar pada mahasiswa dengan peran banyak

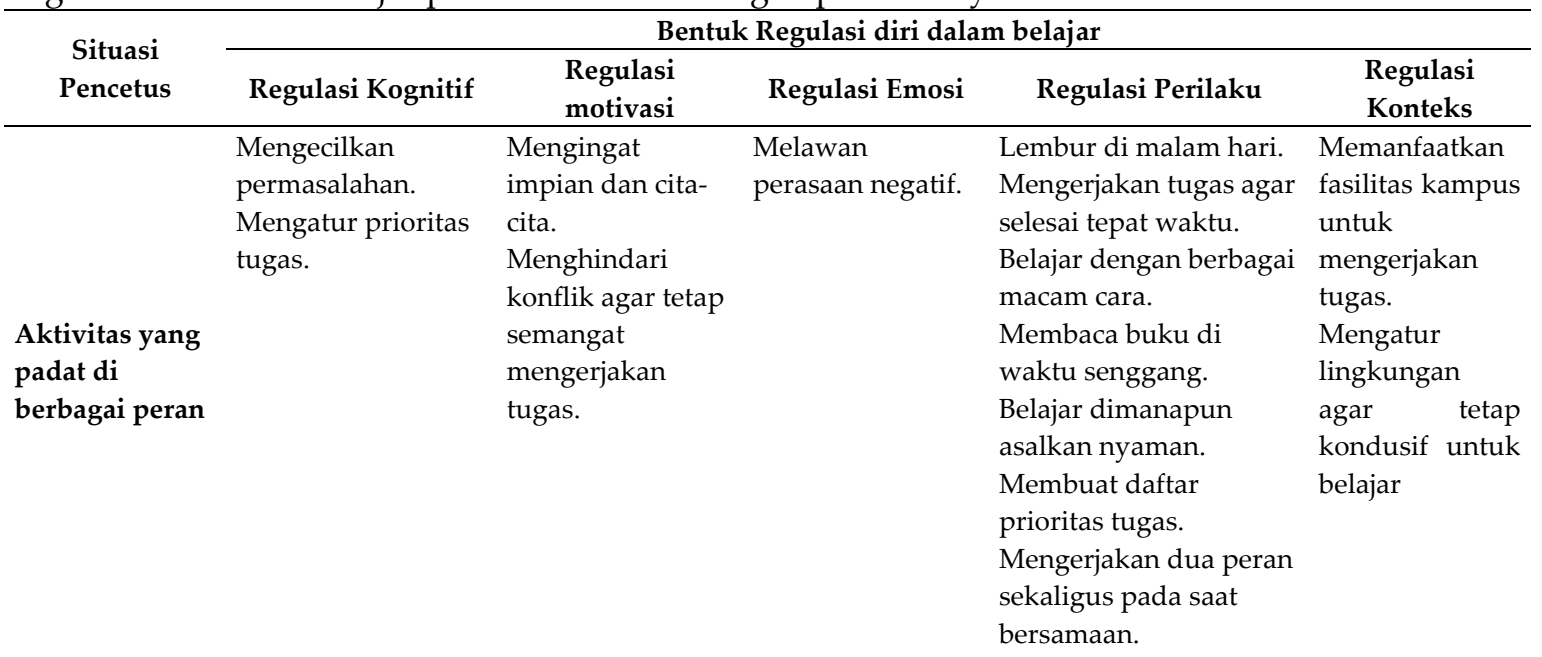

$\begin{array}{ll}\text { Mengurus anak } & \text { Fokus mengikuti } \\ \text { dan rumah } & \text { pembelajaran } \\ \text { tangga ketika } & \text { dikampus. }\end{array}$

di rumah

Cara penilaian

Dosen yang

berbeda
Keinginan

untuk berhasil

dalam

pembelajaran
Fokus untuk tetap

belajar.

Tidak memikirkan

tugas lain saat

mengerjakan tugas

kampus.

Membuat skema

materi pelajaran.

Merubah emosi

negatif menjadi

motivasi dalam

belajar.

\section{Keterbatasan \\ dana untuk \\ pendidikan \\ Hambatan \\ dalam \\ memenuhi \\ tuntutan \\ belajar}

Mengatur waktu

belajar.

Memaksakan diri ke

kampus.

\section{Mengikuti \\ aturan \\ penilaian}

Dosen.
Keinginan agar
tidak gagal dalam
tugas.
Tekad menjadi
contoh yang baik

Memilih tugas

yang disenangi untuk dikerjakan

terlebih dahulu.

Meminimalisir

hal yang tidak

membuat

nyaman.

Berusaha tidak

terpengaruh

emosi negatif.

Menjaga emosi

tetap stabil.
Terlibat aktif

mengerjakan tugas.

Mengumpulkan dan

menyimpan rapi semua materi kuliah.

Mengatur waktu belajar

ketika mau ujian.

Meluangkan waktu

setiap hari untuk

belajar.

Menyelesaikan tugas

sebelum dateline.

Mengerjakan tugas

secara optimal.

Mencatat rapi materi

kuliah.

Menulis ulang semua

catatan kuliah.
Mempertimbang

kan biaya

pendidikan
Menahan emosi

negatif dengan

mengingat semua

ketentuan dari

Tuhan. 
Keempat subjek dalam penelitian ini memiliki tujuan yang sama yaitu mereka berkeinginan dengan melanjutkan pendidikan langkah mereka untuk mencapai jenjang karir yang lebih baik dapat terbuka dengan mudah. Tujuan lainnya adalah keinginan untuk menambah pengetahuan di bidang yang disukai oleh mereka membuat informasi-informasi selama proses pembelajaran di terima dengan antusias. Selain tujuan umum tersebut pada subjek $N E$ terdapat tujuan lain yang lebih khusus dengan melanjutkan pendidikan, yaitu keinginan untuk memberi contoh yang baik bagi anaknya bahwa meskipun memiliki tugas dan kesibukan yang banyak di peran yang lain tetapi ia mampu memberikan hasil yang memuaskan secara akademik. Subjek NE berharap anaknya dapat meniru tekad dan usahanya untuk meraih prestasi yang membanggakan.

Hasil penelitian ini menunjukkan bahwa banyaknya aktivitas yang harus dijalankan oleh subjek membuat mereka mengalami konflik yaitu kesulitan membagi waktu untuk memenuhi tuntutan belajar dengan tuntutan di peran yang lain dan konflik peran karena adanya tekanan di satu peran yang memengaruhi peran yang lain. Konflik-konflik peran ini membuat subjek mengalami kesulitan dalam menjalankan tuntutan belajar sebagai mahasiswa sehingga mereka melakukan regulasi diri dalam belajar untuk membantu memenuhi tuntutan belajar sebagai mahasiswa pascasarjana. Usaha-usaha untuk mengatasi permasalahan maupun usaha dalam menjalankan aktivitas yang banyak di berbagai peran memunculkan berbagai perasaan yang dialami oleh para subjek. Perasaan-perasaan yang muncul dapat berupa perasaan senang, berat, dan perasaan bersalah. Perasaan ini tidak terlepas dari sifat yang dimiliki serta kondisi yang dialami oleh para subjek .
Kesempatan, harapan, tujuan pribadi dan rintangan yang dialami oleh para subjek menjadi suatu kesatuan yang menciptakan arti regulasi diri dalam belajar tersebut untuk mereka. tanpa adanya kesempatan melanjutkan pendidikan, tidak adanya harapan untuk berhasil dan tidak adanya tujuan untuk meningkatkan karir lebih baik maka regulasi diri tidak akan terjadi. Meskipun demikian, dengan adanya kesempatan, harapan, dan tujuan pribadi tidak membuat rintangan dapat dilalui dengan mudah.

Regulasi diri dalam belajar para subjek penelitian merupakan suatu regulasi yang dilakukan dengan melihat situasi, kondisi, faktor pendukung juga karakter pribadi yang dimiliki. Makna regulasi diri dalam belajar ini sendiri bagi para subjek merupakan suatu bentuk pengaturan yang dilakukan dengan mencoba berbagai macam cara sebelum mencapai suatu bentuk pengaturan atau regulasi yang dianggap berhasil mengatasi berbagai tuntutan belajar sebagai mahasiswa pascasarjana ditengah kesibukan membagi waktu dan tenaga di peran yang lain. Regulasi diri dalam belajar ini memunculkan perasaan nyaman, tenang dan menumbuhkan keyakinan diri bahwa diri mereka mampu untuk memenuhi target yang ditetapkan oleh mereka sendiri dalam pembelajaran tersebut, sehingga motivasi berprestasi yang sebelumnya telah dimiliki subjek menjadi semakin kuat.

\section{Diskusi}

Penelitian ini bertujuan untuk melihat gambaran secara utuh berdasarkan perspektif orang yang mengalaminya langsung mengenai regulasi diri dalam belajar yang dilakukan oleh mahasiswa yang juga memiliki peran lainnya yaitu sebagai wanita karir dan ibu rumah tangga. Hasil peneli- 
tian menunjukkan bahwa regulasi diri yang dilakukan oleh mahasiswa dengan peran yang banyak menunjukkan bahwa terdapat regulasi diri dalam belajar berdasarkan regulasi kognitif, motivasi, perilaku dan konteks.

Penelitian-penelitian sebelumnya menyebutkan beragam mengenai regulasi diri dalam belajar pada mahasiswa yang memiliki peran banyak. Penelitian Najah (2012) menemukan bahwa mahasiswa yang telah menikah akan lebih rendah bentuk regulasi diri dalam belajar yang dilakukannya sehingga memengaruhi terhadap prestasi akademik mereka. Hasil penelitian Triana (2014) pada mahasiswa yang bekerja juga menunjukkan bahwa mahasiswa yang bekerja kesulitan dalam mengatur diri dengan baik sehingga tugas akademik mereka menjadi terabaikan akibat tuntutan tugas yang harus dikerjakan. Temuan penelitian ini bertentangan dengan apa yang ditemukan oleh Najah (2012) dan Triana (2014) tersebut. Pada penelitian ini mahasiswa yang memiliki peran banyak (bekerja dan menjadi ibu rumah tangga) tetap dapat melakukan regulasi diri dalam belajar dengan baik meskipun mendapatkan hambatan dalam pelaksanaannya. Akan tetapi, hambatan dan kesulitan tersebut tidak menyurutkan usaha mereka melakukan regulasi diri dalam belajar sehingga prestasi akademik dapat diraih mereka yang terlihat dari IPK yang dicapai yaitu diatas 3.5 pada skala 4 . Faktor yang membuat hasil penelitian ini berbeda dengan penelitian sebelumnya yang bertentangan yaitu adanya motivasi yang tidak diukur maupun diamati pada penelitian yang dilakukan oleh Najah (2012) dan Triana (2014). Motivasi yang kuat pada diri subjek dalam penelitian ini untuk mencapai keberhasilan dalam pendidikan membuat mereka memiliki tekad yang kuat untuk mengatasi berbagai permasalahan di berbagai peran yang mereka hadapi, salah satunya dengan melakukan regulasi diri dalam belajar. Disamping itu motivasi untuk meraih prestasi juga menjadikan subjek berusaha lebih giat dan menyenangi materi yang mereka pelajari di program pascasarjana. Hal ini sebagaimana yang disebutkan oleh Vollmeyer dan Rheinberg (2006) bahwa motivasi merupakan sesuatu yang penting yang dapat membuat seseorang merasa tertarik, tertantang dan membuat mereka percaya dapat memahami materi pembelajaran dengan strategi yang lebih baik serta dapat menikmati proses belajar tersebut.

Temuan penelitian ini yang menunjukkan keberhasilan mahasiswa dengan peran banyak melakukan regulasi diri dalam belajar mendukung hasil-hasil penelitian sebelumnya yang sejalan dengan hasil penelitian ini seperti hasil penelitian Schaie dan Carstensen (2006) yang menemukan bahwa mahasiswa dengan peran sosial lain yang dimilikinya akan melakukan regulasi diri dalam belajar yang lebih tinggi daripada mahasiswa yang tidak memiliki peran sosial lain. Penelitian Mezei (2008) juga mengungkapkan bahwa seorang pembelajar pada usia dewasa meskipun telah bekerja tetap melakukan regulasi diri dalam belajar untuk membantu dalam pemahaman mereka. Motivasi untuk menguasai materi, tidak adanya perasaan terpaksa dalam belajar serta materi pelajaran yang relevan untuk aplikasi di kehidupan kerja membuat regulasi diri dalam belajar dapat terlaksana.

Empat bentuk regulasi diri dalam belajar oleh mahasiswa dengan peran yang banyak dalam penelitian ini yaitu regulasi kognitif, motivasi, perilaku dan konteks mendukung hasil penelitian Pintrich (2004) yang telah lebih dahulu 
menemukan empat bentuk regulasi ini. Hal ini memperkuat konsep regulasi diri dalam belajar yang dikemukakan oleh Pintrich dapat digunakan pula untuk melihat kemampuan mahasiswa dengan peran banyak dalam melakukan regulasi agar proses pembelajaran mereka dapat berhasil.

Regulasi diri dalam belajar yang dilakukan oleh subjek dalam penelitian ini selain melakukan empat asfek regulasi seperti yang telah disebutkan, mereka juga melakukan regulasi emosi yaitu dengan melawan perasaan negatif, memilih tugas yang disenangi terlebih dahulu untuk diselesaikan, meminimalisir hal yang tidak menyenangkan agar jangan sampai memengaruhi emosi, berusaha agar tidak terpengaruh emosi negatif, menjaga emosi tetap stabil diberbagai situasi, dan menahan emosi negatif dengan mengingat semua ketentuan berasal dari Tuhan. Semua bentuk regulasi diri dalam belajar pada aspek emosi ini dilakukan oleh subjek penelitian agar dapat menyelesaikan tugas-tugas akademik mereka. Bentuk regulasi diri dalam belajar pada aspek emosi ini sejalan dengan apa yang disebutkan oleh Hwang (2006) bahwa regulasi emosi merupakan proses unik individu untuk mengatur pengalaman emosional untuk mencapai keinginan sosial dan memperoleh respons utama yang tepat secara fisik dan psikologis terhadap tuntutan instrinsik dan ekstrinsik.

Regulasi emosi yang ditemukan dalam penelitian ini memperluas cakupan bentuk regulasi dalam belajar sebagaimana teori sebelumnya yang menyebutkan regulasi diri dalam belajar terdiri dari empat bentuk yaitu regulasi kognitif, regulasi motivasi, regulasi perilaku dan regulasi konteks. Jika melihat bentuk regulasi emosi yang ditemukan dalam penelitian ini memiliki perbedaan dengan konsep regulasi motivasi Pintrich (2004) yang memasukkan regulasi afeksi sebagai upaya mengatur emosi. Pada konsep Pintrich seseorang dapat memilih dan beradaptasi terhadap suatu strategi untuk mengelola motivasi dan afeksinya. Regulasi emosi yang ditemukan dalam penelitian ini diketahui bahwa regulasi yang dilakukan bukan hanya ketika seseorang memilih dan beradaptasi terhadap suatu strategi agar afeksinya dapat membantu dalam regulasi diri dalam belajarnya, tetapi juga dilakukan pada saat seseorang akan memulai suatu kegiatan pembelajaran seperti ketika akan mengerjakan tugas. Regulasi emosi yang dilakukan pada subjek penelitian ini berupa pengaturan terhadap emosi yang dirasakan merupakan langkah awal agar proses pembelajaran yang dilakukan dapat dijalankan dengan baik. Jadi dapat dikatakan pengaturan emosi dilakukan terlebih dahulu sebelum strategi pembelajaran atau regulasi pada aspek yang lain dilakukan. Bentuk regulasi emosi dalam penelitian ini kiranya lebih mendekati konsep regulasi emosi yang dikemukakan oleh Gross (2007) bahwa regulasi emosi mencakup; (1) strategies to emotion regulation yaitu keyakinan individu untuk dapat mengatasi suatu masalah, memiliki kemampuan untuk menemukan suatu cara yang dapat mengurangi emosi negatif, dan dapat dengan cepat menenangkan diri kembali stelah merasakan emosi yang berlebihan, (2) engaging in goal directed behavior yaitu kemampuan untuk tidak terpengaruh oleh emosi negatif yang dirasakan sehingga dapat tetap berpikir dan melakukan sesuatu yang baik, (3) control emotional responsses ialah kemampuan individu untuk dapat mengontrol emosi yang dirasakannya dan respons emosi yang ditampilkan (respons fisiologis, tingkah laku, dan nada suara) sehingga individu tidak akan merasakan emosi 
yang berlebihan dan menunjukkan respons emosi yang tepat, serta (4) acceptance of emotional responsse yaitu kemampuan individu untuk menerima suatu peristiwa yang menimbulkan emosi negatif dan tidak merasa malu merasakan emosi tersebut.

Penelitian empat aspek regulasi emosi pada keempat subjek sebagaimana diutarakan oleh Gross (2007) terdapat pada regulasi subjek. Para subjek berupaya menemukan cara agar emosi negatif yang dirasakan dapat segera hilang dan tugastugas mereka dapat segera diselesaikan. Para subjek juga melakukan kontrol terhadap emosi mereka dan tidak terpengaruh dengan lingkungan berlama-lama seperti menghindari konflik dengan orang lain agar tidak memengaruhi emosi yang dapat mengganggu pengerjaan tugas. Subjek juga mampu menerima diri bahwa tidak selamanya mereka dapat menjaga emosinya positif adakalanya muncul rasa sedih, kecewa ketika strategi regulasi yang mereka lakukan tidak berhasil atau ketika menghadapi masalah.

Mahasiswa dengan peran yang banyak mampu membentuk regulasi diri dalam belajar yang tepat sehingga mereka dapat mencapai tujuan yang diharapkan dalam proses pembelajaran. Adanya regulasi diri dalam belajar ini tidak terlepas dari motivasi berprestasi yang mereka miliki. Motivasi berprestasi ini berperan dalam membangkitkan semangat para subjek agar dapat mencapai prestasi akademik yang baik dan berupaya semaksimal mungkin. Motivasi berprestasi yang dimiliki para subjek diperkuat dengan regulasi terhadap motivasi ketika subjek mengingat impian dan cita-cita. Selain itu regulasi motivasi ini juga muncul di saat subjek memiliki keinginan agar tidak gagal dalam tugas, bertekad menjadi contoh yang baik, mempertimbangkan biaya pendidikan yang harus dikeluarkan jika selesainya kuliah tertunda, serta menghindari konflik agar tetap semangat mengerjakan tugas. Zimmerman (1990) menyebutkan ketika seseorang memahami mereka adalah individu yang kreatif, bertanggung jawab, mampu mengembangkan diri dan menentukan tujuan mereka, maka diri mereka sendiri akan memberikan motivasi yang diperlukan untuk melakukan regulasi diri dalam belajar.

Regulasi diri dalam belajar yang dilakukan tidak selalu menghasilkan tercapainya sasaran yang ditentukan oleh subjek penelitian. Salah satu subjek penelitian juga dapat mengalami hambatan dan tidak mampu sepenuhnya dalam melakukan regulasi diri dalam belajar, seperti subjek $S$ yang mengalami kendala menyelesaikan tesisnya ketika merasakan dilema antara pekerjaan yang harus segera diselesaikan (kewajiban menulis buku ajar) dengan keharusan untuk menulis tesis. Meskipun ia telah mengupayakan untuk dapat mencapai target yang ia tentukan yaitu segera mengerjakan tesis agar kuliahnya segera selesai sebelum dua tahun masa studi, akan tetapi ia belum dapat fokus untuk memulai mengerjakan tesisnya. Faktor lain yang membuat ia tidak dapat segera menyelesaikan tesisnya dikarenakan sikapnya yang perfectionis dalam semua tugas yang dibuat. Kegagalan dalam memenuhi target seperti yang dilakukan oleh subjek $S$ ini sejalan dengan penyataan dari Pintrich (2004) yang menyebutkan bahwa perspektif regulasi diri dalam belajar mengasumsikan seorang pembelajar memiliki potensi untuk dapat mengontrol dan meregulasi beberapa aspek pada diri mereka seperti kognisi, motivasi, perilaku dan juga beberapa aspek lingkungan mereka. Asumsi ini bukan berarti bahwa individu akan dapat 
memantau dan mengontrol kognisi, motivasi ataupun perilaku mereka setiap saat atau dalam semua konteks. Perspektif regulasi diri dalam belajar mengakui bahwa ada peran biologis, perkembangan, kontekstual dan kendala perbedaan individu yang dapat menghambat atau mengganggu individu melakukan regulasi.

Faktor situasi yang menjadi pencetus terhadap terjadinya regulasi diri dalam belajar pada mahasiswa dengan peran banyak juga tidak dapat diabaikan peranannya. Situasi seperti aktivitas yang padat diberbagai peran, kewajiban mengurus anak dan keluarga ketika berada dirumah, keinginan untuk berhasil dalam pembelajaran, keterbatasan dana untuk pendidikan, hambatan dalam memenuhi tuntutan belajar, dukungan yang diberikan orang terdekat menjadi faktor-faktor yang menyebabkan mahasiswa melakukan berbagai bentuk regulasi diri dalam belajar yang berbeda. Hasil penelitian ini dimana regulasi diri dalam belajar mengikuti dari faktor pencetus merupakan sesuatu yang tidak dapat diabaikan begitu saja dalam memahami regulasi diri dalam belajar pada mahasiswa dengan peran banyak selain faktor karakteristik individu atau kepribadiannya. Dapat dikatakan bahwa bentuk regulasi diri dalam belajar yang muncul tidak akan terjadi jika tidak disebabkan oleh faktor pencetus dan karakteristik individu atau kepribadiannya tersebut. Mezei (2008) juga menyebutkan bahwa terdapat perbedaan individual dalam regulasi diri dalam belajar yang dilakukan seperti kapasitas kemampuan untuk melakukan regulasi yang berbeda tiap individu.

Para subjek dalam penelitian ini tinggal dalam lingkungan keluarga yang menjunjung tinggi nilai-nilai agama dan budaya. Subjek penelitian juga nampak memiliki perilaku religius baik dalam menjalankan ibadah maupun dalam bertingkahlaku sehari-hari dan menerapkan prinsip hidup yang terkait dengan nilai-nilai budaya Jawa. Hal ini menunjukkan bahwa ajaran agama dan budaya (Jawa) menjadi landasan bagi mereka dalam bertingkahlaku termasuk dalam melakukan regulasi diri dalam belajar. Pentingnya peranan nilai-nilai agama dan budaya dalam membentuk regulasi diri dalam belajar sejalan dengan apa yang dikemukakan oleh Turingan (2009) yang mengungkapkan bahwa nilai budaya terhadap pendidikan yang dianut individu akan berpengaruh terhadap regulasi diri dalam belajar. Hal ini disebabkan karena budaya akan mengarahkan individu dalam berpikir dan berperilaku.

Mahasiswa dengan peran banyak dalam penelitian ini melakukan regulasi diri dalam belajar berupa mengingat semua ketentuan dari Tuhan agar tidak kecewa dan berputus asa, untuk menjaga motivasi mereka dalam belajar dan memenuhi tuntutan belajar sebagai mahasiswa pascasarjana. Bentuk regulasi diri dalam belajar ini menunjukkan bahwa ada peranan Tuhan yang diyakini oleh subjek dalam kehidupannya (external locus of control) sebagaimana ajaran agama Islam maupun Kristen yang mengharuskan manusia untuk berusaha dalam menjalankan suatu aktivitas dan mendasarkan semua usaha yang dilakukan pada ketentutan dari Tuhan, seperti yang tertera dalam kitab Al-Qur'an dan kitab Injil. Akan tetapi, meskipun para subjek meyakini peranan Tuhan dalam kehidupan mereka, regulasi diri dalam belajar berupa regulasi perilaku tetap dipertahankan dengan melakukan berbagai kontrol terhadap perilaku demi mencapai keberhasilan dalam pembelajaran.

Bentuk regulasi diri dalam belajar yang muncul juga dipengaruhi oleh 
budaya dimana para subjek tinggal dan dibesarkan, dalam hal ini budaya jawa. Salah satu sikap yang dianggap menonjol pada orang Jawa adalah ketergantungannya pada masyarakat (Jatman, 2011). Regulasi yang dilakukan oleh subjek dapat dikatakan juga tidak terlepas dari peranan keluarga yang memberikan dukungan dan membantu tugas-tugasnya di peran yang lain sehingga mereka dapat fokus dalam memenuhi tuntutan sebagai mahasiswa dan mengerjakan tugas-tugas kuliahnya. Bantuan yang diberikan oleh keluarga seperti misalnya membantu pekerjaan rumah tangga, mengurus anak ketika subjek harus kuliah dan bantuan dari anggota perkumpulan yang mengambil alih tugas dalam suatu kegiatan kepanitian.

Regulasi diri dalam belajar yang dilakukan yaitu dalam hal regulasi kognitif, regulasi motivasi, regulasi perilaku, regulasi emosional dan regulasi konteks menjadi modal yang besar bagi para mahasiswa dengan peran banyak untuk mendapatkan prestasi akademik yang baik. Indeks prestasi yang tergolong tinggi menjadi bukti bahwa meskipun aktivitas mereka di berbagai peran sangat banyak dan padat, akan tetapi mereka masih bisa menunjukkan bahwa mereka mampu mencapai prestasi akademik. Pintrich (2004) sendiri telah mengungkapkan bahwa kemampuan untuk mengendalikan usaha seseorang dan ketekunan dalam menghadapi hal yang sulit, membosankan, atau nilai tugas yang rendah merupakan suatu strategi regulasi diri yang penting. Mahasiswa adakalanya memiliki banyak pilihan, kontrol dan tuntutan di akademik, sosial dan pribadi sehingga mereka harus belajar untuk mengelola waktu dan usaha agar sukses.

Regulasi konteks yang ditemukan dalam penelitian ini lebih mengacu kepada bentuk regulasi dengan mengatur konteks mahasiswa itu sendiri dalam menghadapi lingkungan yang kurang kondusif menjadi lebih kondusif sehingga tuntutan belajar maupun keberhasilan dalam suatu pembelajaran dikelas dapat dicapai dengan baik. Para subjek berusaha untuk membuat diri mereka merasa nyaman dengan mengikuti alur yang tepat sehingga proses belajar tersebut dapat berjalan dengan lancar. Para subjek nampak berupaya untuk merubah pandangan mereka yang awalnya lingkungan belajar mereka tidak kondusif atau tidak sesuai dengan harapan dirubah dengan menganggap lingkungan tersebut menjadi tempat yang nyaman untuk belajar dan mengikuti proses pembelajaran sesuai keinginan pengajar. Hal ini sesuai dengan yang diutarakan oleh Schunk (2005) bahwa regulasi konteks meliputi persepsi seseorang terhadap tugas dan konteks.

Keyakinan yang dimiliki oleh subjek penelitian menjadi dasar untuk mempertahankan usaha dalam mengatasi berbagai tuntutan belajar. Cobb (2003) menyebutkan salah satu faktor yang memengaruhi regulasi diri dalam belajar selain motivasi dan tujuan adalah keyakinan diri (self efficacy). Ketika mahasiswa dengan peran banyak yakin bisa mengatasi tuntutan belajar dengan aktivitas yang banyak di berbagai peran mereka, maka akan menghasilkan upaya yang konsisten pula dalam mengatasi tuntutan tersebut. Akan tetapi, ketika situasi pencetus membuat dilema dalam menentukan prioritas tugas mengakibakan keyakinan mereka menurun dan mengurangi upaya yang dilakukan dalam memenuhi tuntutan belajar di perguruan tinggi, seperti yang terjadi pada subjek $S$. Hal ini menunjukkan bahwa regulasi diri dalam belajar tidak terlepas dari situasi pencetus yang membuat terjadinya regulasi, motivasi, dan keyakinan mahasiswa itu sendiri. 


\section{Kesimpulan}

Dari hasil penelitian ini dapat disimpulkan beberapa hal yaitu: (1) Regulasi diri dalam belajar membuat mahasiswa yang memiliki peran sosial yang lain yaitu sebagai wanita karir dan ibu rumah tangga dapat meraih prestasi akademik yang tinggi. (2) Bentuk regulasi diri dalam belajar yang ditemukan adalah regulasi kognitif, regulasi motivasi, regulasi emosi, regulasi perilaku dan regulasi konteks, dan (3) Regulasi diri dalam belajar dapat dipengaruhi oleh berbagai faktor seperti karakteristik individu atau kepribadian, ajaran budaya dan agama yang dianut, motivasi, keyakinan diri dan situasi pencetus yang menyebabkan munculnya proses regulasi.

\section{Saran}

Sebagai upaya prerventif, mahasiswa yang memiliki peran yang sama dengan subjek dalam penelitian ini dapat mempertimbangkan strategi regulasi dalam belajar yang dilakukan oleh para subjek dan mengantisipasi kemungkinan-kemungkinan situasi yang dapat terjadi dengan mempersiapkan atau merencanakan strategi regulasi diri dalam belajar yang dapat dilakukan dalam hal regulasi kognitif, regulasi motivasi, regulasi emosi, regulasi perilaku dan regulasi konteks. Sebagai upaya pengembangan keilmuan penelitian terkait dengan regulasi dalam belajar khususnya regulasi emosi yang ditemukan dalam penelitian ini dapat dijadikan pertimbangan sebagai salah satu bentuk regulasi untuk melihat regulasi diri dalam belajar yang dilakukan oleh mahasiswa.

\section{Kepustakaan}

Badan Pusat Statistik. (2012). Angka Partisipasi Murni (APM) menurut Tipe Daerah, Jenis Kelamin dan Jenjang Pendidikan. Diunduh dari: http://www.bps.go.id/ tanggal 30 Mei 2012.

Cheng, E. C. (2011). The role of self regulated learning in enhancing learning performance. The International Journal of Research and Review, 6(1), 116.

Cobb, R. (2003). The relationship between self regulated learning behavior and academic performance in Web-Based Course. (Disertation, unpublished). The Fakulty of Virginia Polytechnic institute and state university. Diunduh dari: http://Scholar.lib.Vt.edu./ tanggal 23 Agustus 2013.

Gross, J. J. (2007). Handbook of Emotion Regulation. New York: Guilford Press.

Hwang, J. (2006). A Processing Model of Emotion Regulation Insight from The Attahment System. Disertation. George State Uniersity. College of Arts and Science.

Irawaty \& Kusumaputri, E. S. (2008). Pengaruh Manajemen Diri terhadap Intensitas Konflik Peran Ganda (Studi pada Wanita yang Bekerja di Lembaga Pendidikan). Phronesis Jurnal Ilmiah Psikologi Industri dan Organisasi, 10(1), 14-33.

Jatman, D. (2011). Psikologi Jawa. Yogyakarta: Kayoman.

Kuswarno, E. (2009). Fenomenologi, Konsepsi, Pedoman, dan Contoh Penelitian. Bandung: Widya Padjajaran. 
Latifah, E. (2010). Strategi self regulated learning dan prestasi belajar: kajian meta-analisis. Jurnal Psikologi, 37(1), 110-129.

Mezei, G. (2008). Motivation and selfregulated learning: A case study of a pre-intermediate and An upperintermediate adult student. WoPaLP, 2, 79-104.

Moleong, L. J. (2011). Metodologi Penelitian Kualitatif. Edisi Revisi. Bandung: Remaja Rosdakarya

Montalvo, F. T., \& Gonzalez, M. C. (2004). Self regulated learning: current and future directions. Electronic journal of research in educational psychology, 2(1), 1-34. Diunduh dari: http://www. investigacionpsicopedagogica.com/rev ista/articulos/3/eng-lish/ Art_3_27.pdf tanggal 18 Agustus 2013.

Moustakas, C. (1994). Phenomenological Research Methods. London: Sage Publication, Inc.

Najah, A. (2012). Self regulated learning mahasiswa ditinjau dari status pernikahan. Educational Psychology Journal, $1(1), 17-24$.

Pintrich, P. R. (2003). A motivational science perspective on the role of student motivation In learning and teaching contexts. Journal of Educational Psychology, 95(4), 667-686. http://dx. doi.org/10.1037/0022-0663.95. 4.667

Pintrich, P. R. (2000). An achievement goal theory perspective on issues in motivation terminology, theory, and research. Contemporary Educational Psychology, 25, 92-104. http://dx.doi.org /10.1006/ceps.1999.1017.

Pintrich, P. R. (2004). A conceptual framework for assessing motivation and self regulated learning in college student. Educational Psychologist, 16(4), 385-407.

Puwanto, N. A. (2009). Keefektifan Belajar Mandiri Mahasiswa Program Studi pendidika Anak Usia Dini Universitas Terbuka UPBJJ Yogyakarta. Depdikbud: Universitas Terbuka.

Rescoe, G., Morgan, C. J., \& Peebles, C. (1996). Student who work. Kentucky; Libra publisher. Diunduh dari: http:// scholar.lib.vt.edu/ejournal/JVER/v25n4 /stone.html. tanggal 08 September 2013.

Santrock, J. W. (2007). Educational psychology. Canada: McGrawHill Companies, Inc.

Schaie, K. W., \& Carstensen, L. L. (2006). Social Structure, Aging, and Self Regulation in The Elderly. New York: Springter Publishing Company.

Schunk, D. H. (2005). Self regulated learning: the educational legacy of Paul R. Pintrich. Educational Psychologist, 40(2), 85-94.

Setyawati, P. (2010). Fenomena Konflik Pekerjan-Keluarga kaitannya dengan Performansi Kerja (sebuah studi fenomenologi). (Tesis tidak dipublikasikan). Fakultas Psikologi Universitas Gadjah Mada, Yogyakarta.

Spitzer, T. M. (2000). Predictor of college success: a comparison of traditional and contraditional age student. NASFA Journal 38, 82-98. Diunduh dari: http://publication.nasfa.org/cgi. viewcontent.cgi?article $=1130$ and contex =nasfajournal. tanggal 07 Desember 2014

Thomas, J., Raynor, M., \& Al-Marzooqi, A. (2012). Marital status and gender as predictors of undergraduate academic performance: a United Arab Emirates context. Learning and Teaching in Higher Education: Gulf Perspectives 9(2). Diun- 
duh dari: http://lthe.zu.ac.ae._tanggal 23 November 2014.

Triana. K. A. (2013). Hubungan antara orientasi masa depan dengan prokrastinasi dalam menyusun skripsi pada mahasiswa Fakultas Ilmu Sosial dan Ilmu Politik (Fisipol) Universitas Mulawarman Samarinda. E-Journal Psikologi, 1(3), 280-291.

Turingan, J. P. (2009). A Cross-Cultural Comparison of Self-Regulated Learning Skills between Korean and Filipino College Students. Asian Social Science, 5(12), 3-10.
Utami, D. S. (2011). Strategi Work-life Balance pada Dosen Perempuan Berperan Ganda (Studi Kasus di Program Studi Arsitektur). (Tesis tidak dipublikasikan). Fakultas Psikologi Universitas Gadjah Mada, Yogyakarta.

Vollmeyer, R., \& Rheinberg, F. (2006). Motivational effects on self-regulated learning with different tasks. Educational Psychology Review, 18, 239-253.

Zimmerman, B. J. (1990). Self regulated learning and academic achievment: an overview. Educational Psychologist, 25(1), 3-17. 